\title{
DIE ROL VAN DIE PRIESTER IN DIE 'TROONOPVOLGINGSGESKIEDENIS'
}

F.N. Lion-Calchet

Departement Ou Testament

Potchefstroomse Universiteit vir $\mathrm{CHO}$

POTCHEFSTROOM

\begin{abstract}
Abstracl
The so-called 'Silccession Narrative' or 'Court Histony' (2 Sam. 9-10 and I Kings 1-2) bears very litle testimony to the role of the priests. This article represents an atlempl to examine the position of the priestly community, the priestly office-bearers and their office, the pan played by the priests in the crowning of the king and the fulfilmen of their office to detennine the role of the priests in the histony of revelation ('theologn') as sesn in the Succession Narrative. It will becone clear that the priestly order was inded not very prominent and that there were many shortcomings. This however, was part of the fulfilment of God's covenan promises that there would be a successor to David. While Giod did not specifically use the priests in the succession to David's throne, the pricsts were not ignored in the revelation since their presence and their officiating emphasized the presence of the L.orrl.
\end{abstract}

\section{INILEIDING}

L. Rost het in 1926 geoordeel dat 2 Samuel 9-20 en 1 Konings 1-2 as 'n selfstandige bron valn boeke oor Samuel en Konings beskou kan word, en hy het dit die Troonopvolgingsgeskiedenis ("Die Überlieferung von Thronnachfolge Davids") genoem. Sedert 1926 is Rost se hipotese byna algemeen aanvaar alhoewel daar tog nog baie kriticse vrae gevra word (vgl. Kaiser, 1988:5; Ackroyd, 1981:388-390; Von Rad, 1963:312-316; Wharton, 1981:342-343; Gunn, 1976:228-229; Van Seters, 1983:277; Co:11s, 1981:377-380; Eissfeldt, 1966:138 en Flanagan, 1972:181; Stoebe, 1973:48). Volgens Rost (1926) is die Troonopvolgingsgeskiedenis 'n propagandastuk om die troomopvolging van Salomo te regverdig en dus in majorem gloriam Salmonis geskrywe (vgl. ook 0.a. McCarter 1981:357). Hierdie gedagte is egter minder algemeen aanvaar (Childs, 1979:276; McCarter, 1984:10-11). As aanvaar word dat die koningsgeskiedenis en in besoncier die troonopvolging die sentrale tema van bogenoemde bron is, kan die vrailg gevra word wat die rol van die priesters in hierdie geskiedenis is.

As dic mededelinge in Salnuel en Konings met dié van Kronieke vergelyk word, is dit oppervlakkig gesien, duidelik dat die priesterhiërargie (hoëpriester, priester, Leviet) en 
priesterdiens skynbaar minder aandag kry as in die Kroniekeboeke. Alhoewel die woord kôhên (ekv. en mv.) $113 \mathrm{keer}$ in die boeke Samuel en Konings gebruik word (in die Troonopvolgingsgeskiedenis word dit 24 keer gebruik), teenoor $107 \mathrm{keer}$ in Kronieke, word die begrip Leviet of Leviete egter net drie keer in die boeke Samuel en Konings (net een keer in die Troonopvolgingsgeskiedenis) gebruik, maar 93 keer in Kronieke. Die woordgebruik bevestig egter nie die werklike posisie van die priesterhiërargie nie. 'n Nadere ondersoek van die afgebakende Skrifgedeelte, 2 Samuel 9-20 en 1 Konings 1-2 (die Troonopvolgingsgeskiedenis) ten opsigte van die betekenis van die priesterlike lewe kan 'n interessante bydrae lewer tot die verstaan van God se openbaring in die worsteling om 'n opvolger op die Dawidstroon te kry. In die navorsing van die openbaringshistoriese gebeure soos wat dit in hierdie teks opgeteken is, kan rekening gehou word met die feit dat baie gebeurtenisse in dié spanningsvolle verhaal wentel rondom die vraag 'wie sal op Dawid se troon sit?' (vgl. 1 Kon. 1:20 en 27). Gaan dit egter net om die koningsopvolging as sodanig? Wat was die rol van die priesterkorps? Was hulle net 'n deel van 'n drukgroep wat vir die koning propaganda gemaak het (vgl. 1 Kon. 1:7)? Wat was hulle taak ten opsigte van die koning en wat belangriker is, wat was hulle besondere taak ten opsigte van God? Het God hulle vir 'n besondere doel gebruik? In hierdie ondersoek sal op die priesters in hierdie tyd gekonsentreer word om hulle plek in die openbaring van God vas te stel.

Die finale opgetekende teks word aanvaar as 'n gesagvolle getuienis van die openbaring van God in die geskiedenis. Die kennis wat God aan ons wou deurgee, is opgeskrywe. In die verklaring van die teks sal 'n openbaringshistoriese metode gebruik word (vgl. Hasel, 1985:100-102). 'n Literêre en historiese beoordeling is in die konteks van die openbaringsgeskiedenis gebruik veral om enige subjektiewe rekonstruksies te vermy. Die ondersoek konsentreer op die priestergemeenskap, die twee priesters Sadok en Abjatar, die priesterlike ampsbediening, die aandeel van die priesters in die kroning van die koning en hulle selfstandige ampsbeoefening. Op dié manier kan die plek van die priesters bepaal word in hierdie stukkie openbaringsgeskiedenis.

\section{DIE PRIESTERGEMEENSKAP IN DIE TROONOPVOLGINGS- GESKIEDENIS}

Die konings en die volk het 'n hoë agting vir die priesters gehad en het gedurig met hulle rekening gehou (vgl. die feit dat Samuel die konings gesalf het: 1 Sam. 10:1; 16:13, en die huiwering van die dienaars van Saul om die priesters by Nob dood te maak: 1 Sam. 22:17). Saul was gefrustreerd en het ongebalanseerd opgetree toe hy sonder goeie motivering die 85 priesters by Nob brutaal laat doodmaak het (vgl. 1 Sam. 22:17-19). Hierdie daad van Saul het nie die posisie van die priesters totaal of 
permanent geskaad nie. Toe die priester Abjatar met die skouerkleed ontvlug het en die Urim en die Tummim met hom saamgeneem het, was hy die een wat die voorreg behou het om voor die HERE te verskyn (1 Sam. 22:20; 23:6). Dawid was op Ajatar aangewese om die HERE te raadpleeg, en Abjatar het dit waarskynlik deur die Urim en die Tummim gedoen (vgl. 1 Sam. 23:2).

Alhoewel daar nie skerp op die priesters gefokus is nie, het dit nie hulle diens en belangrikheid weggeneem nie. Dit is waar dat daar min van die priestergemeenskap as geheel meegedeel word en dat die begrip priester of priesters meesal net in apposisie met Sadok en Abjatar gebruik is. Hierdie verwysings na die priesters bevestig die feit dat die Aäronitiese priesterinstelling in die koningstyd gefunksioneer het. As die twee belangrikste priesters genoem is, kan ons veronderstel dat daar 'n groter priestergemeenskap was (vgl. Dommershausen, 1984:74). Volgens Levitikus was die priesterinstelling ook reeds lank bekend. (Die hipotese dat Levitikus in sy geheel aan $P$ toegewys is, en alleen in 'n na-ballingskapse verband verstaan kan word, word deur baie vervang met sieninge dat baie wette in Levitikus in verskillende vroeëre periodes en kontekste ontstaan het - vgl. Childs, 1979:182-186; Rendtorff, 1985;145. Daar kan ook aan die Moses-era gedink word - vgl. Lion-Cachet, 1990:94.) In 2 Samuel 15:24 word die Leviete wat deel uitmaak van die kultusdiensgemeenskap by name genoem. Die diens van die Leviete was tot ondersteuning van die priesters en sou sonder die priesters in 'n lugleegte te staan gekom het. Dit mag wees dat daar 'n verandering in hulle posisie gekom het en dat huile diens in die ballingskaptyd en daarna sterker ontplooi het.

Die vroeë bestaan van die priesters word algemeen erken. Die priesterdom is volgens Dommershausen (1984:77) 'n ouer instelling as dié van die koningskap, alhoewel die priesterinstelling eers onder die koningskap tot volle ontplooiing gekom het. Cross (1973:195) oordeel dat Wellhausen se teorie dat daar in 'n vroeër fase van die lewe van Israel wel dienaars in die heiligdomme was, maar sonder 'n vaste, erflike priesterskap, nog algemeen aanvaar word. Cody (1969:107) meen dat

\footnotetext{
... Israclite ideas of both monarchy and priesthood, ... went through a process of developmen from the carly days of the monarchy, when the kings performed acts which had about them a character that was indisputably priestly in an ancient Semitic sense, and the later days of the monarchy, when the growth of pricstly power led more and more to the reservation of properly sacral functions to professional priests (vgl. ook De Vaux, 1961:292-293; Feinberg, 1975:858; Curtis, 1877:799).
}

Die titel hoëpriester kom nie in die Troonopvolgingsgeskiedenis voor nie. Sekere inligting kan egter verkry word uit die gegewens rondom die twee priesters, Sadok en Abjatar. In 1 Konings 2:35 word Sadok in die plek van Abjatar aangestel. Dit is heel natuurlik om hierdie aanstelling as 'n aanstelling in 'n hoër pos met groter verantwoor- 
delikheid te beskou en kan die aanstelling van 'n hoëpriester veronderstel word. Die hoëpriester was nie altyd as hoëpriester aangedui nie. In baie gevalle het hy as die eerste onder gelykes opgetree (vgl. Eks. 28-29 en Curtis, 1877:85-86). Cody (1969:103) is van oordeel dat daar voor die ballingskap geen hoëpriester was nie alhoewel daar op 'n paar plekke in Konings van 'n hoëpriester sprake is (2 Kon. 12:11 (10); 22:4,8; 23:4). De Vaux (1961:267) noem dit tekswysiginge. Dit is myns insiens eenvoudiger om die lyn van Aäron tot by die Troonopvolgingsgeskiedenis deur te trek as om hierdie gegewens as tekswysiginge of glosse te beskou. Die naam van Sadok word altyd voor Abjatar genoem terwyl hulle albei tog priesters was. Sou dit nie gepas gewees het dat die naam van die hoëpriester altyd eerste genoem moet word nie? Fohrer (1973:213) en Dommershausen (1984:74) hou ook rekening met 'n priesterhoof of hoëpriester in die tyd van die monargie. Olyan (1982:190 e.v.) beklemtoon weer Sadok se belangrikheid as 'n priester uit 'n Suid-Judaïstiese tradisie.

Van die weinige kere waar van Leviete in Samuel en Konings sprake is, is een in die Troonopvolgingsgeskiedenis: 2 Samuel 15:24. Die Leviete het saam met Sadok en Abjatar Jerusalem verlaat om saam met Dawid te vlug en die Leviete het die ark gedra. Hieruit is verskillende afleidings gemaak: onder andere dat daar in die begin geen onderskeid tussen die priesters en die Leviete gemaak is nie (De Vaux, 1961:242246; vgl. Feinberg, 1975:858), of dat Leviete 'n later toevoeging is (Hertzberg, 1964:3439). Die Kehatiete, 'n nie-priesterlike geslag uit die Levietestam is aangewys om die ark te dra (vgl. Num. 3:31; 4:15). Op 'n paar plekke is vermeld dat die Levietiese priesters die ark gedra het (Deut. 31:25; Jos. 3:3,6,13,14,17; 6:6; 1 Kon. 8:3). In 2 Samuel 15:24-29, waarin vertel is dat Dawid voor Absalom gevlug het, het die Leviete die ark in teenwoordigheid van die priesters Sadok en Abjatar gedra en die vervoer daarvan beheer. Hierdie traumatiese gebeurtenis was 'n heel besondere geleentheid sodat hulle teenwoordigheid by die vervoer gepas was. Hoe dit ook al sy, ons kan wel sê dat die Leviete in die Troonopvolgingsgeskiedenis gefunksioneer het.

In 2 Samuel 20:23-26 is 'n lys van Dawid se ampsdraers gegee. Die orde en die name wat genoem word, verskil van die lys in 2 Samuel 8:16-18. In hoofstuk 20:23-26 is 'n logiese orde gegee: eers die militêre, dan die burgerlike en daarna die priesterlike leiers. In hoofstuk 8:16-18 is die name ('stilisties') in 'n soort konsentriese orde gegee:

(A) 'n Militêre leier (Joab), (B) 'n burgerlike leier (Josafat) en dan volg die name van die priesters (Sadok en Abjatar) wat die sentrum van die lysie is. Die name van die leiers van die ampte word nou in omgekeerde orde genoem: (B1) 'n burgerlike (Seraja) en (A1) 'n militêre leier (Benaja). Daarna word die seuns van Dawid genoem. 'n Mens verwag dat hulle in die orde van die skema by die militêre personeel gereken sou word maar in die teks word hulle priesters genoem. 
Die noem van die seuns van Dawid as priesters is onverwags en in stryd met die feit dat Dawid nie uit die priesterlike geslag was nie en sy seuns ook nie daar hoort nie. Die seuns is priesters genoem maar hulle het seker eerder as militêre leiers of burgerlike ampsdraers diens gedoen. In hoofstuk 20:23-26 word die seuns van Dawid nie weer in die lys genoem nie maar wel die naam van die priester Ira. Die feit dat Ira, die Jaïriet, 'n priester genoem is, word verskillend beoordeel. Is hy dieselfde man as die held Ira, die Jitrict, wat in 2 Samuel 23:38 genoem is (vgl. Goslinga, 1962:265)? Hertzberg (1964:375) oordeel dat Ira, die Jairiet, die funksie van die seuns van Dawid oorgeneem het. Jaiir is in elk geval uit die Manassestam (Num. 32:41; Rigt. 10:3) en as hy as priester diens gedoen het, is dit in die lig van die Levitiese priesterskap ook 'n onreëlmatigheid. Daar was in die tyd van die rigters en die vroeë koningstyd seker meer onreëlmatighede (vgl. Rigt. 7:5 en 2 Sam. 8:18). Dat die seuns van Dawid priesters genoen is en clat daar onreëlmatighede in die Ira-geval kon wees, bevestig sekere tekortkominge malar dit hoef nie noodwendig tot die konklusie te lei dat die hele priesterinstelling primitief en totalal ongeorganiseerd was nie.

Uit bogenoemde is dit dus duidelik dat die hiërargiese priesterinstelling soos dit in die Levietestam ingebed is, en soos dit in Eksodus en Levitikus beskrywe is, in die Troonopvolgingsgeskiedenistyd gefunksioneer het. Daar kon wel sekere onreëlmatighede gewees het.

\section{DIF: PRIISSIERIIKE AMPSBEKI EDERS: SADOK EN ABJATAR}

In die geskiedenis van die konings is die kombinasie Sadok en Abjatar spreekwoordelik en word dit minstens sewe kecr aangetref. In die lys van ampsdraers in 2 Samuel 8:16-18 word Sadok en Abjatar nader aangedui deur hulle familieverbande ook te noem. Sadok is die seun van Ahitub en Ahimeleg word die seun van Abjatar genoem. Dic vriag is of ons nie alu Abjatar die seun van Ahimeleg moet dink nie (vgl. I Sam. $22: 20$ en 23:6)? Baie aanvaar dat ons in 2 Samuel $8: 17$ in vergelyking met 'n Siriese teks walt $A$ himeleg die seun van Abjatar noem, met 'n tekskritiese fout te doen het. Die Septuagint lui egter soos die Masoretiese teks en dit kom ook ooreen met die bewoording van 1 Kronicke 18:16. Daar is geen dwingende rede om hier van die Masoretiese teks af te wyk nie. Die moeiliker verklaring is hier die mees alanvaarbare. Goslinga (1956:19-120) vra of ons nie moet dink aan 'n ander Ahimeleg wat 'n seun van Abjatar is nic, maar kom tot die konklusic dat ons in 2 Samuel 8:17 tog Abjatar die seun van Ahimeleg moet lees. Miskien is dit die beste dat ons aanvaar dat ons met twee variante of tradisies te make het. Wat wel belangrik is, is dat ons van twee belangrike priesters te hore kom.

In die Troonopvolgingsgeskiedenis ontmoet ons Sadok vir die eerste keer in 2 Samuel 
15:24. Baie ontken die historiese betroubaarheid van Kronieke (vgl. Cross, 1973:212; Olyan, 1982;177) en die genealogieë word ook bevraagteken. So word Sadok se Aäronitiese (en Levitiese) afstamming betwyfel. Hy het dan uit 'n onbekende geslag te voorskyn gekom (vgl. De Vaux, 1961:260). Verskillende moontlikhede word dan aan die hand gedoen (vgl. Cody, 1969:89-91; De Vaux, 1961:260 e.v.), onder andere dat Sadok eers 'n onbekende priester in Gibeon was (vgl. 1 Kron. 16:39), of 'n priester uit die geslag van Melgisedek wat voor Dawid in Jerusalem diens gedoen het (die Jubusiet-hipotese, vgl. Olyan, 1982;179; Cross, 1973:209). Olyan soek na 'n SuidJudese oorsprong (1982:190 e.v.). Daar is ook voorgestel dat ons "Agjo" in 2 Samuel 6:3 e.v. "achjw" ("sy broer") moet lees. Hierdie broer van Ussa is dan eintlik Sadok, wat 'n priester in Kirjat-Jearim was (vgl. Cody, 1969:90). Ussa en "sy broer" was egter die seuns van Abinadab en in 2 Samuel 8:17 word Sadok die seun van Ahitub genoem (vgl. ook 1 Kron. 5:34 (6:8)).

Om ' $n$ antwoord te kry, is dit beter om weer na 1 Kronieke 5:30-41 (6:4-15) te kyk. Hier moet ons wel rekening hou met sekere oneffenhede in Kronieke in vergelyking met ander Ou-Testamentiese gegewens, maar hierdie oneffenhede is geen bewuste verdraaiings wat die boek onbetroubaar maak nie. Dit kan as 'n diverse bydrae in die weergawe van die openbaring gesien word. Die aard van die bydrae kan alleen deur eksegese vasgestel word (vgl. Childs, 1979:642-645; Noordtzij, 1957:26-45; Van Dyk, 1987:90). In 1 Kronieke 5:30-41 (6:4-15) kry ons inderdaad'n stylvolle genealogie. De Vaux (1961:262-263) wys daarop dat daar 'n bewuste simmetrie te bespeur is (12 generasies tussen die tabernakel en die tempelbou, dit wil sê tot by Ahimaäs, en 12 generasies tot by die herbou van die tempel, dit wil sê tot by Josua, wie se naam nie in Kronieke genoem word nie maar in Haggai 1:1). Daar is dan ook sekere priestername weggelaat. In Kronieke word die naam van Johanan egter aan die tempel van Salomo in Jerusalem gekoppel en die naam van Josua word nie genoem nie. Sekere name is weggelaat en die name Amarja, Ahitub en Sadok word in 'n ongelyke reëlmaat herhaal. Ons hoef egter nie noodwendig te konkludeer dat ons hier met 'n onbetroubare geslagsregister te make het nie. Dit kan wees soos dit aan ons oorgelewer is: 'n geslagsregister wat kunstig gekonstrueer is. Die skrywer van Kronieke het 'n ander doel voor oë gehad as om 'n bloot chronologiese lys op te stel. Die funksie van die register is ter wille van kunstige en sosiologiese faktore anders ingeklee (vgl. Dillard, 1980:216-217). Dat Sadok afstam van Eleasar, 'n seun van Aüron, hoef nie betwyfel te word nie. De Vaux (1961:262) het ook die moontlikheid oopgelaat om Sadok as iemand van Levitiese oorsprong te beskou (vgl. ook Cross, 1967:212-215). En waarom nie?

Abjatar was die seun van Ahimeleg, die seun van Ahitub, die seun van Pinehas, die seun van Eli (1 Sam. 14:3; 22:9). Eli word self nie aan ons bekend gestel nie, maar is volgens 1 Kronieke 24:3 uit die geslag van Itamar en het so tot die Levietestam behoort (vgl. ook Num. 3:4; 25:11-13). Abjatar het aan die priestermoord by Nob 
ontkom (1 Sam. 22:20) en het hom by die voortvlugtende Dawid gevoeg. As draer van die efod en die Urim en die Tummim (vgl. 1 Sam. 23:2 e.v.) het hy as hoëpriester onder Dawid diens gedoen (vgl. Hertzberg, 1964:343). In die Troonopvolgingsgeskiedenis word Abjatar altyd na Sadok genoem. Dit is moontlik omdat Sadok die sterkere figuur was en na die verbanning van Abjatar as hoëpriester aangestel is. Die Sadokitiese priesterskap is ook in sy nageslag bevestig. Die Qumran-gemeenskap het later geoordeel dat hulle die nageslag van Sadok is (La Sor, 1970:326). Abjatar het Adonia as troonopvolger verkies (1 Kon. 1:7-8). Wat sy motivering vir hierdie keuse was, is nie gesê nie. Van Gelderen (1937:24) stel die vae moontlikheid dat Abjatar gemeen het dat hy meer onder Adonia sou kon regkry as onder Salomo. Of het Abjatar werklik geoordeel dat Adonia meer ervaring gehad het en dus meer vir die amp geskik was? As draer van die ark en getroue dienaar van Dawid is Abjatar nie weens sy aandeel in die sameswering gedood nie maar hy word later na Anatot verban en so van sy amp as hoëpriester onthef. So het die vloek oor die huis van Eli in vervulling gegaan (vgl. 1 Sam. 2:27-36). Sy priesterlike nageslag word tog later in die profeet Jeremia (Jer. 1:1) teruggevind. Cross (1973:215) stel dat Dawid twee 'hoëpriesters' benoem het: "... he chose a priest from each of the great, rival priestly families: Abiathar of the Shilonite house of Eli which claimed descent from Moses, Zadok from the Hebron clan which traced its line to Aaron". Op die manier het hy nie een van die priesterhuise vervreem nie. Salomo het Sadok en die Sadok-Aäronitiese huis bevoordeel (vgl. ook Brongers, 1967:45).

\section{DIE PRIESTERLIKE AMPSBEDIENING}

Die etimologie van kôhên is onseker. Sommige dink aan die Akkadiese kânu $\left(k^{\prime} n\right)=$ buig, hulde bring, of die Arabiese kâhin = waarsêer, of aan kûn = staan. Die priesters word nou verbind met die diens by 'n heiligdom of in die tempel. Hulle is die bewaarders van die heiligdom, terwyl die heiligdom 'n sigbare en simboliese uitdrukking is van die teenwoordigheid van God by die mense. Die priesters is diegene wat voor God staan en as middelaars tussen God en die mens optree (vgl. Dommershausen, 1984:72; Vriezen, 1966:400; Eichrodt, 1961:404; Curtis, 1877:16).

Die priesterdiens was in die Ou Ooste wel bekend en het in sowel Egipte as Mesopotamië 'n taak gehad (vgl. Bergman, 1984:64-65; Ringgrin, 1984:66-67). In die Ou Testament het die priesters in die heiligdomme opgetree en dit bewaak. Hulle het as middelaars God ten behoewe van die mense geraadpleeg om dan weer God se antwoord aan die mense mee te deel. Dit is hier waar die gebruik van die Urim en die Tummim 'n beslissende rol gespeel het (vgl. Deut. 33:8). In hulle kultiese diens het hulle offers gebring. Verder was hulle die onderrigters en bewaarders van die wet (Dommershausen 1984:72 e.v.; Fohrer, 1973:211-213). 


\subsection{Hulle wat voor die Here staan en Hom raadpleeg}

In die Troonopvolgingsgeskiedenis het die priesters in die teenwoordigheid van die ark beweeg ( 2 Sam. 15:24-29) en Dawid kon van die dienste van Abjatar gebruik mak om die HERE te raadpleeg. Hy het dit voor die tyd gedoen (vgl. 1 Sam. 22:12-17; 30:7-8; 2 Sam. $2: 1 ; 5: 19,23)$. In 1 Samuel 30:7-8 word uitdruklik vermeld dat Abjatar die skouerkleed gebring het sodat Dawid die HERE kon raadpleeg. Waarom het Dawid in sy geveg tcen die Ammoniete en die Arameërs (2 Sam. 10) of in sy vlug voor Absalom (2 Sam. 15) nie die HERE geraadpleeg nie? In plaas daarvan om die HERE te raadpleeg, het hy Sadok en Abjatar na Jerusalem toe teruggestuur om as luistervinke op te tree en op 'n puur menslike wyse inligting na hom deur te stuur. Hy vra wel vir Sadok of hy 'n siener is (2 Sam. 15:27), maar dit is nie duidelik wat tog daarmee bedoel word nie. Is dit 'n verwyt (Goslinga, 1962:198), of moet ons dit verstaan as 'n oproep ("Thou seer! return into the city ... "; vgl. Keil, 1950:421) soos dit in die Septuagint vertaal is? Hoe dit ook al sy, dit is opvallend dat Dawid nie vir'n Godspraak gewag het nie. Hy het die priesters na Jerusalem teruggestuur. Die vraag kan miskien die beste beantwoord word as ons op Dawid se skuldgevoel let. Hy vlug onder die besef van sy sonde met Batseba en die oordeel wat oor sy huis hang (2 Sam. 12:11). Hy vra nie na die HERE nie omdat hy nie die vrymoedigheid daartoe het nie (Ps. 32:3). Dit is egter moeilik om Abjatar se optrede te verstaan. As 'n verantwoordelike priester wat die skouerkleed by hom gehad het, kon hy die HERE geraadpleeg het. Hy het egter ' $n$ instrument in die hand van Dawid geword en het nie soos voorheen die HERE geraadpleeg nie. Hierdie nalatige optrede kan ook die sleutel wees om die twyfel oor die besluit oor wie die troonopvolger moet wees, te verstaan.

\subsection{Hulle was die bewaarders en die onderrigters van die wet}

'n Deel van die priesterlike taak was die bewaring en die onderrig van die wet (Deut. 33:10). Dit beteken dat die priesters die nakoming van die bepalinge en insettinge van die wet moes onderrig en die volk (en die koning) moes vermaan. Hulle moes steeds die oproep laat hoor: "Hoor, Israel, die HERE jou God is 'n enige HERE ... daarom moet jy die HERE jou God liefhê." In die Troonopvolgingsgeskiedenis word geen vermanende woord van die kant van die priesters gehoor nie. In hierdie opsig is die traagheid in hulle getroue ampsvervulling opmerklik.

\subsection{Hulle offerdiens}

Die offerdiens word in Deuteronomium 33:10 aan die priesters opgedra (vgl. ook Hebr. 5:1 en 8:3). Helberg (1976:239-241) oordeel dat die offerdiens as diens van 
versoening 'n uiters belangrike plek ingeneem het. In die sondige atmosfeer waarin baie van die gebeure plaasgevind het, sou die simboliese versoeningsoffers baie gepas gewees het. Die groot verskeidenheid offers het die mens in teenwoordigheid van God gebring maar het die mens ook die afstand tussen God en die mens laat besef. Offers was belangrik maar dit het ook nie die hele kultiese instelling oorheers nie. Die gewone lewe van die priesters en die volk in die monargiese periode het in baie opsigte 'n ander prentjie vertoon (vgl. die bespreking van die offers by Fohrer, 1973:156-158, 205-211).

In die Troonopvolgingsgeskiedenis is daar net een moontlikheid om aan die bring van 'n offer te dink. In 2 Samuel 15:24 staan wajja'al 'ebjâtâr. Die hif'il van 'âlâh word meermale gebruik om die bring van 'n offer aan te dui. Gewoonlik word offer as voorwerp daarby genoem. In die NIV is dit dan ook so vertaal: "and Abjatar offered sacrifices". Dit verklaar waarom Abjatar se naam nie aan die begin van die vers genoem is nie en dit lyk asof dit 'n laat invoeging is. Dan het ons wel 'n gepaste versoenoffer. Die meeste vertalings het egter die gedagte behou dat Abjatar ook opgetrek het.

Ons moet ook daarop wys dat die offerdiens van die priesters in Samuel - Konings net twee keer genoem of veronderstel word (1 Sam. 2:12-17,28,29 en 2 Kon. 16:15,16). God se openbaring het die klem dus nie op die seremoniële offerdiens laat val nie.

\section{DIE PRIESTERI IKE AANDEEL AAN DIE 'KRONING' VAN DIE KONING}

In die 'kroning' van 'n koning in Israel, was die plasing van die kroon op die hoof van die koning nie die hoogtepunt van die gebeure nie. Dit was selfs nie 'n wesenlik belangrike handeling nie. Die salwing was wel belangrik en word dikwels genoem. Die gebruik om die koning te salf, was nie tot Israel alleen beperk nie maar het in die hele Ou Ooste voorgekom (vgl. De Vaux, 1961:I 186 e.v.). Die salwing is in Israel beskou as die simbool van die verkiesing van God en dit is bevestig as die Gees oor die aangewese persoon vaardig geword het (vgl. 1 Sam. 10:10). Die salwing het van die een wat gesalf is, ' $n$ besondere persoon gemaak. Hy is as die 'gesalfde', die 'messias' beskou.

Die taak om te salf was nie besonderlik aan die priesteramp verbind nie. Fohrer (1973:205) beskou die deelname van die priesters aan die kroningsritueel as 'n ongewone openbare seremoniële taak. Die profete, wat die wil van God moes openbaar, het dit meer as een keer gedoen: Samuel het Saul en Dawid gesalf, 'n profeet het Jehu gesalf (2 Kon. 11:12). In 1 Konings 1:32-40 het Dawid die opdrag aan die priester Sadok en die profeet Natan gegee om Salomo te salf. Die 'hoëpriester' Abjatar word 
verbygegaan, moontlik omdat hy 'n ondersteuner van Adonia was. In die Biblia Hebraica Stuttgartensia word voorgestel om die woorde "en Natan, die profeet" in verse 34 en 45 as 'n interpolasie te skrap omdat die naam van Natan nie in vers 39 voorkom nie en die salwing deur een persoon gedoen word. Behalwe die verwysing na een manuskrip, is daar egter geen ander tekskritiese getuienis nie. Dit is trouens meer sinvol om "Natan, die profeet" in vers 39 (soos in die Siriese manuskripte) te behou. 'n Salwingseremonie waarin twee persone optree, is wel moontlik. Die teenwoordigheid van 'n gesagvolle profeet en 'n amptelike priester by die salwingseremonie was van groot betekenis. Dit is opmerklik dat die woorde van Benaja, die hoof van die leër, die wentelpunt vorm in die konsentriese gekonstrueerde perikoop, 1 Konings 1:32-40. Hy spreek die seën oor die nuwe koning uit. Joab, ook 'n ondersteuner van Adonia, is ook verbygegaan.

Die priester Sadok kon van die 'heilige' salfolie gebruik het wat heel moontlik in die tent was wat Dawid as heiligdom opgerig het (vgl. 2 Sam. 6:17). Sadok, wat later in die plek van Abjatar die hoëpriesterlike funksie vervul het, was simbool van die mens en die volk wat voor God gestaan het.

\section{DIE SELFSTANDIGE AMPSBEOEFENING VAN DIE PRIESTERS}

Dit lyk of daar in die Troonopvolgingsgeskiedenis weinig sprake was van 'n onbelemmerde en roepingsbewuste optrede van die priesters. Hulle was deel van die koninklike amptenary (2 Sam. 20:23-26) wat deur die koning benoem en verban was ( $2 \mathrm{Kon}$. $2: 26-27,35)$. Dit lyk asof hulle in alles die koning se wil uitgevoer en nooit enige sameswering, soos Jojada teen Atalia, teen hom beplan het nie. As van hulle wel ander gedagtes gekoester het, soos blyk uit die onderhandeling met Abjatar (1 Kon. 1:7), is diegene wat so gedink het, uitgeskakel. Hulle het as die koning se informante en boodskappers gedien ( 2 Sam. 15:35-37; 17:17-20) en moes as tussengangers dien om die volk te beïnvloed (2 Sam. 19:11-14). Cody (1969:102) merk dan op dat die priesters priesters vir die koning was en nie priesters vir God nie (vgl. Rigt. 17:5,10,12; 18:4.19; en in 2 Sam. 20:26).

Moet ons nie liewer daaraan dink om die koning as 'n soort 'hoëpriester' te beskou nie? Dit het in ou Sumerië en Egipte voorgekom (vgl. Cody, 1969:98-100). Dawid het buite die Troonsopvolginsgeskiedenis om tog sekere priesterlike funksies waargeneem (vgl. 2 Sam. 6:17-18;24:25). Dit is egter waar dat 'kerk' en 'staat' in die Israelitiese volkslewe nie waterdig van mekaar geskei kon word nie. Dit is waar dat die koning die oorheersende figuur in Israel geword het, maar die priesters het tog 'n eie selfstandigheid behou. Die priesters was uit die geslag van Levi en net die Leviete kon as priesters gedien het. Onreëlmatighede in dié verband, het nie die reël opgehef nie. Dit 
was die HERE wat sy priesters geroep het (vgl. 1 Sam. 2:35) en hulle was in hulle diepste wese priesters vir Hom (vgl. 1 Kon. 2:27 : 'et-'Ebjâtâr ... kôhên Lhwh).

Dit is daarom merkwaardig dat die koning nie in die kwessie rondom die Troonopvolging, die priester Abajatar gevra het om die HERE te raadpleeg deur die Urim en die Tummim nie. Dit is ook merkwaardig dat die 'hoëpriester' in hierdie moeilike saak dit nie self gedoen het nie. Abjatar het sonder om die HERE te raadpleeg aan Adonia voorkeur gegee. Hierdie nalatigheid het hom uiteindelik sy amp gekos. Die priesters het ten opsigte van hierdie saak nie hulle amp selfstandig beoefen nie en het mondstukke van die koning geword.

\section{KONKLUSIE}

* In die Troonopvolgingsgeskiedenis val die fokus nie op die priesters nie. Daar word weinig van hulle instelling en huishouding (in teenstelling met Kronieke) vermeld; byna net Sadok en Abjatar en sommige van hulle seuns word genoem; die priesters word nie geraadpleeg nie; die priesters vermaan ook nie die ander wat die wet oortree nie en die hoëpriester raadpleeg nie die HERE nie. Daar is 'n klein moontlikheid dat van die offerdiens melding gemaak is, en by die salwing van die koning tree 'n priester saam met 'n profeet op. Die priesters is traag en ook skuldig aan die vervulling van hulle roeping.

* Waarna soek ons egter in die Troonopvolgingsgeskiedenis? Gaan dit nie primêr dataroor om meer van die handelinge van die HERE met sy volk te wete te kom nie? Hy het in sy verbondstrou aan Dawid'n nageslag belowe en Hy hou sy beloftes in stand ten spyte van sondige mense wat in hulle menslike liefde en voorkeure, haat, intriges, ambisies, vernedering, samesweringe en ontrou so min van die ware wederliefde tot Hom betoon het. Salomo word koning ten spyte van die sondige Dawid en die swygende priesters. As Natan die bevel ontvang om mee te help met die salwing van die koning, doen hy dit en ontvang nie weer van die HERE, soos in 2 Samuel 7:5-16, die bevel om die koning in die uitvoering van sy planne tcë te gaan nie.

* Ons leer God se openbaring in die Troonopvolgingsgekiedenis in 'n ware profetiese perspektief ken. Daar word genoeg van die priesters vertel. Hulle is diegene wat voor God staan, wat tot Hom kan nader en sy woord kan bring. Dawid word gedurig deur die priesters gekonfronteer, hulle is daar en hy hou met hulle rekening. Hulle is daar by die salwing van die nuwe koning, die nuwe messias. Die priesters by wie daar in hierdie stadium van die geskiedenis nie groot charismatiese persoonlikhede is nie, word genoem omdat hulle op 'n heel formele manier, 
die teenwoordigheid en nabyheid van die HERE beklemtoon. Hulle word genoem ten spyte van hulle swakhede en sondighede want hulle het in God se openbaring 'n onvervangbare plek gehad.

\section{BIBLIOGRAFIE}

ACKROYD, P.R. 1981. The Succession Narrative (so called). Interpretation, XXXV (4) :383-393. BERGMAN, J. e.a. 1984, kohen. (In Bottcrweck, G.J. \& Ringgren, H., red. Theologisches Wörterbuch zum Alten Testament IV. Stuttgart : Kohlhammer.)

BRONGERS, H.A. 1967. I Koningen. (POT). Nijkerk : Callenbach.

CHILDS, B.S. 1979. Introduction to the Old Testament as Scripture. London : SCM.

COATS, (B.W. 1981. Parable, fable and anecdote. Storytelling in the Succession Narrative. Interpretation, $\mathrm{XXXV}(4): 368-382$.

CODY, A. 1969. A history of Old Tustament priesthood. Rome : Pontifical Biblical Institute.

CROSS, F.M. 1973. Cananite myth and Hebrew epic. Essays in the history of the religion of Isracl. Cambridge, Massachusetts : Harvard Univ.

CURTIS, S.I. (Jr.) 1877. The Levitical priests. Edinburg: T \& T Clark.

DE VAUX, R. 1961. Hoe het Oude Israel leefde, I \& II. Roermond-Maaseik: Romen \& Zonen.

DILLARD, R. 1980. The reign of Asa (2 Chronicles 14-16): An example of Chronicler's theological method. JETS 23(3):207-218.

DOMMERSHAUSEN, W. c.a. 1984. kohen. (In Botterweck, (i.J. \& Ringgren, H., red. Theologisches Wörterbuch zum Alten Testament IV. Stuttgart : Kohlhammer.)

EICHRODT, W. 1961. Theology of the Old Testament, I. London : SCM.

EISSFELDT, O. 1966. The Old Testament. An introduction. Oxford : Basil Blackwell.

FEINBERG, C.L. 1975. Priests and Levites. (In Tenney, MC. ed. The Zondervan pictorial encyclopedia of the Bible. Grand Rapids : Zondervan.)

FLANAGAN, J.W. 1972. Court History or Succession Document? A study of 2 Samual 9-20) and 1 Kings 1-2. $J B L, 91: 172-181$

FOHRER, G. 1973. History of Israclite religion. [Translated by D.E. Green.] London : S.P.C A.A.

GOSLINGA, C.J. 1956. De bocken Samucl. (KV). Kampen : Kok.

GOSLINGA, C.J. 1962. Het tweede bock Samucl. (COT). Kampen : Kok.

GRAY, J. 1964. 1 \& 2 Kings. (OTL). London: SCM.

GUNN, D.M. 1976. Traditional composition in the "Succession Narrative". VT XXVI,(2):214-229

HASEL, G.F. 1985. Biblical interpretation today. Lincoln, Nibraska : College View Printers.

HELBERG, J.L. 1976. Openbaringsgeskiedenis van die Ou Testament, I. Potchefstroom: Pro Rege.

HERTZBERG, H.W. 1964. I \& II Samuct. (OTL). London : SCM.

JACOB, E. 1964. (1955). The theology of the Old Testament. London : Hodder \& Stoughton.

KAISER, O. 1988. Becobachtugen zur sogenannten Tronnachfolgecrzaclhung Davids. ETL, (64 (1):5-20).

KEIL, C.F. 1950. The books of the Kings. (irand Rapids : Ecrdmans.

LASOR, W.S. 1977). I \& Il Kings. (NBCR). London : Inter-Varsity.

LION-CACHET, F.N. 1990. Dic ecrste boeke van dic Ou Testament. Potchefstroom : DSP.

McCARTER, P.K. (Jr.) 1981. "Plots, true or false". The Sucession Narrative as court apologetic. Interpretation, XXXV,(4):355-367.

McCARTER, P.K. (Jr.) 1984. II Samucl. A new translation with introduction, notes and commentary. (Anchor Bible). Garden City : Doubleday.

NOORDTZIJ, A. 1957. De boeken der Kronieken, I. (KV). Kampen : Kok.

OLYAN, S. 1982. Zadok's origens and the tribal politics of David. $J B L, 101(2): 177-193$.

RENTDORF, R. 1985. The Old Testament. An introduction. London : SCM. [Transl. by J. Bowden.]

ROST, L. 1926. Die Überlieferung von der Thronnachfolge Davids. BWANT III No. 6. 
RING(;RIN, H. e.a. 1984. kohen. (In Botterweck, G.J. \& Ringgren, H., red. Theologisches Wörterbuch zum Alten Testament IV. Stutigart : Kohlhamer.)

STOEBE, H.T. 1973. Das crste Buch Samuelis. Kommentar zum Alten Testament. Güterslow : Mohn. VAN DYK, P.J. 1987. Die kronistiese geskiedwerk. (In Bosman, H.L. \& Loader, J.A. reds. Vertellers van die Ou Testament. Kaapstad : Tafelberg. p. 75-99)

VAN (jELDEREN, C. 1937. De boeken der Koningen. Kampen : Kok.

VAN SETERS, J. 1983. In search of history. Historiography in the Ancient World and the origins of Biblical history. New Haven : Yale University.

VON RAD, G. 1963. Old Testament Thcology, 1. Edinburgh : Oliver and Boyn.

VON RAD, G. 1964. Deuteronomy. (OTL). London : SCM.

VRIEZEN, Th.C. 1966. Hoofdlijnen der Theologie van het Oude Testament. Wageningen : Vecnman.

WHARTON, J.A. 1981. A plausible talc. Interpretation, XXXV (4):341-354. 
